
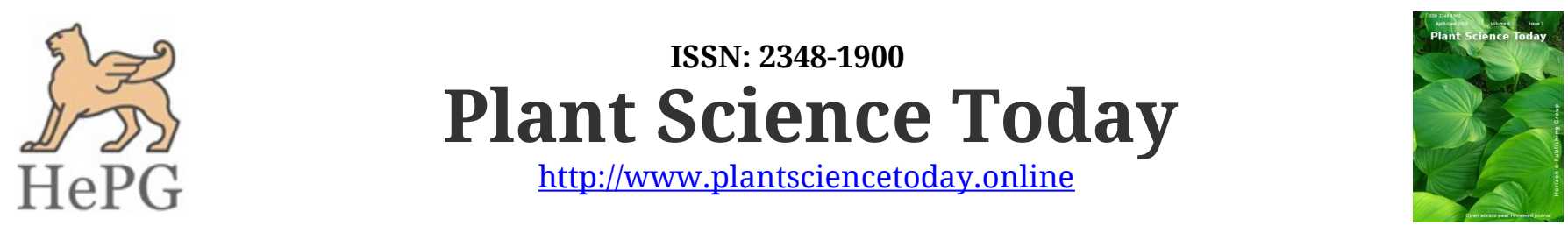

OPEN ACCESS

Research Communication

\title{
Effect of organic amendments on soil salinity and the growth of maize (Zea mays L.)
}

\author{
Monowara Khatun $^{1}$, Md Asif Rahan Shuvo ${ }^{1}$, Md Tareq Bin Salam ${ }^{1 *}$, S M Hafizur Rahman ${ }^{2}$ \\ ${ }^{1}$ Soil, Water \& Environment Discipline, Khulna University, Khulna, Bangladesh \\ ${ }^{2}$ Faculty of Agriculture, Bangladesh Agricultural University, Mymenshing, Bangladesh
}

\section{Article history}

Received: 27 January 2019

Accepted: 10 March 2019

Published: 01 April 2019

\section{Editor}

Dr. Radka Podlipná

Institute of Experimental Botany CAS

Lysolaje, Czech Republic

\section{Publisher}

Horizon e-Publishing Group

\section{*Correspondence \\ Md. Tareq Bin Salam \\ $\square$ tareqss ku@rocketmail.com}

\begin{abstract}
Soil salinity is a major concern in southwestern part of Bangladesh because almost $30 \%$ cultivable lands are currently lying under risk of salinity where $30-50 \%$ yields loss is happening. Organic amendments have found to be effective in the amelioration of saline soil by improving soil physical and chemical properties as well as crop selection is another criteria for sustaining viability of crops in saline soil. For ensuring sustainable saline soil management, a comparative pot study was carried out during kharif 1 season in 2015 to observe the effect of organic amendments (solid waste, vermicompost and cow dung) on soil salinity and its influence on the growth of maize. Composite soil was collected at a depth of 0 $15 \mathrm{~cm}$ from Gozalmari village of Jalma Union in Batiaghata Upazila under Khulna district, Bangladesh that was saline $(10.6 \mathrm{dS} / \mathrm{m})$ in nature and the irrigation water sample was collected from beside Kazibacha river $(4.28 \mathrm{dS} / \mathrm{m})$ that was also moderately saline. The maize cultivar "Shuvra" was used for cultivation in the study. The experiment comprised of four treatments viz. T0: Control (No organic manure); T1: Solid waste (36g); T2: Vemicompost (72g); T3: Cow dung (33g). Five seeds were sown in each pot. Seeds were treated with Agrosan GN to protect them from seed and soil borne pathogens. Chemical fertilizers were not used in the experiment. Irrigation was done two times before harvesting: at 20 days after sowing (DAS) and at 40 DAS with river water and rain water was irrigated naturally during the season. Findings were that the organic amendments significantly influence the physicochemical properties of the saline soil. All organic treated soils significantly reduce the soil EC (from $10.6 \mathrm{dS} / \mathrm{m}$ to $3.4 \mathrm{dS} / \mathrm{m}$ ) and $\mathrm{pH}$ (from 7.63 to 7.38 ) compared to control soil $(p \leq 0.05$ ). In case of survival parameters (e.g \%gemination, rate of survival at 50 DAS) of maize, the treatments were found insignificant $(p \geq 0.05)$. But in terms of growth parameter (plant height and root length), significant differences were found between control and organic amendments treated soil $(p \leq 0.05)$. It may be concluded that organic amendments treated soils showed better results than that of control soil. If proper management can be implemented, this positive results will bring hope to the local poor farmers at least can introduce a new crop in fallow agricultural land during the kharif 1 season.
\end{abstract}

Keywords: EC; maize; organic amendments; river water irrigation; soil salinity

Citation: Khatun M, Shuvo MAR, Salam MTB, Rahman SMH. Effect of organic amendments on soil salinity and the growth of maize (Zea mays L.). Plant Science Today 2019;6(2):106-111. https://doi.org/10.14719/pst.2019.6.2.491

Copyright: ( ) Khatun et al (2019). This is an open-access article distributed under the terms of the Creative Commons Attribution License, which permits unrestricted use, distribution, and reproduction in any medium, provided the original author and source are credited (https://creativecommons.org/licenses/by/4.0/).

Indexing: Plant Science Today is covered by Scopus, CAS, AGRIS, CABI, Google Scholar, etc. Full list at http://www.plantsciencetoday.online 


\section{Introduction}

Soil salinity is a major concern to agriculture because it affects almost all plant functions (1). Usually $30-50 \%$ yield losses occur depending on the level of soil salinity. Over $30 \%$ of the cultivable area of Bangladesh lies in the coastal and offshore zones. Out of 2.86 million hectares of coastal and offshore lands, about 1.056 million hectares are affected by varying degrees of salinity (2). Batiaghata Upazila is situated in the eastern side of Khulna District in the Division of Khulna, Bangladesh. The areas of the Upazila are seasonally flooded with saline water of the Kazibacha river which causes various degrees of soil salinity. In this area farmers grow mostly low-yielding, traditional rice varieties during the wet season. Most of the lands remain fallow in the Kharif-1 season (January-May) because of increasing soil salinity and the lack of good-quality irrigation water $(3,4)$. Both organic and inorganic amendments are found to be effective in the amelioration of saline soils. Organic matter decomposition and plant root action also help dissolve the calcium compounds found in most soils, thus promoting reclamation of saline soil (5). Various organic amendments such as farmyard manure, compost, poultry manure and mulch can be used for the amelioration of saline soils. Organic amendments improve physical, chemical and biological properties of soils under saline conditions (6). Leithy et al. (2010) (7) conducted an experiment on study the effect of saline water addition to bio and organic fertilization treatment on geranium plant growth, mineral and chemical constituents. Salinity affected most of the morphological parameters and decreased the growth performance. The use of peanut compost increased plant height, number of branches and Fresh and dry weights. Maize (Zea mays) is the third most important cereal crop after rice and wheat in Bangladesh and is grown under a wide spectrum of soil and climatic conditions. It is an important C4 plant from the Poaceae family and is moderately sensitive to salt stress (8). Well drained fertile

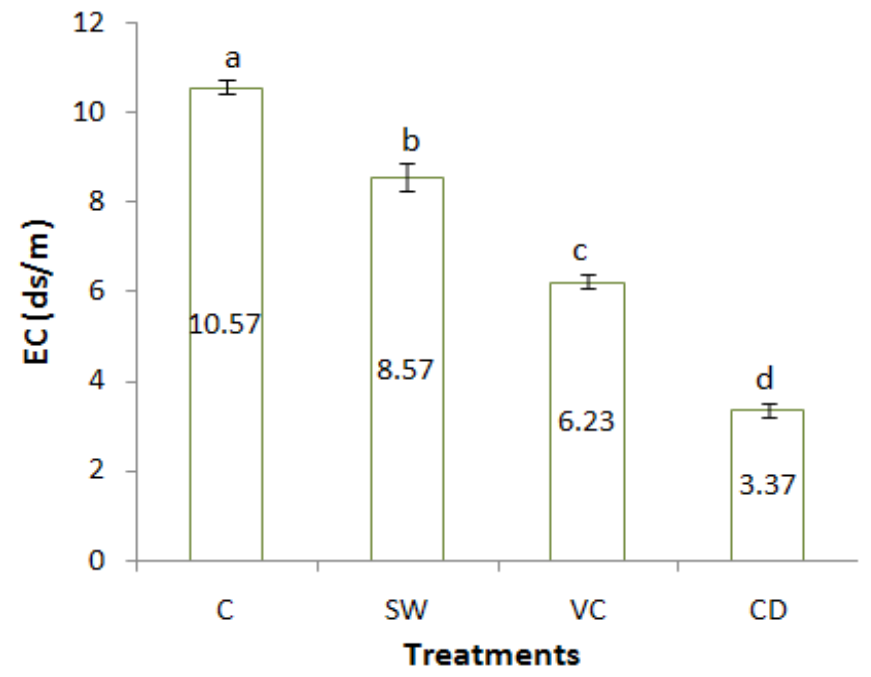

Fig. 1: Effect of organic amendments treated soil on soil EC sandy loam or loamy soil is the best for maize. However, it can be grown in clay soil with adequate drainage facilities (9). It can therefore be grown throughout the year in the sub-tropical climate of Bangladesh. If proper amendments can be introduced, the farmers can be benefited by introducing a new crop in fallow agricultural field during the Kharif 1 season. Due to this reason, a scientific study was undertaken to determine the effect of solid waste, vermicompost and cow dung as organic amendments on the saline soil and its influence on the growth of maize.

\section{Materials and Methods}

\section{Site description and sample collection}

The soil sample was collected from Gozalmari village of Jalma Union in Batiaghata Upazila under Khulna district, Bangladesh with the geographic location $22^{\circ} 46^{\prime} 125^{\prime \prime} \mathrm{N} 89^{\circ} 31^{\prime} 773^{\prime \prime}$ E. The soil was clay, slightly alkaline in reaction ( $\mathrm{pH}, 7.63)$, saline (EC, $10.6 \mathrm{dS} / \mathrm{m}$ ), noncalcareous in nature, high in soil fertility containing medium organic matter (1.05\%). Composite soil samples were collected at a depth of $0-15 \mathrm{~cm}$ and the water sample was collected from nearby Kazibacha River. The maize cultivar "Shuvra" was used for cultivation in the study.

Table 1: Methods of analysis

\begin{tabular}{ll}
\hline Parameters & Methods of analysis \\
\hline Soil Texture & Hydrometer method \\
\hline EC (dS/m) & $\begin{array}{l}\text { electrochemically at 1:5 soil: water ratio as } \\
\text { suggested by USDA }\end{array}$ \\
\hline $\mathrm{pH}$ & $\begin{array}{l}\text { electrochemically at 1:2.5 soil: water ratio as } \\
\text { suggested by Jackson }\end{array}$ \\
\hline $\begin{array}{l}\text { Organic } \\
\text { Matter }\end{array}$ & Walkley \& Black's wet oxidation method \\
\hline Available Na & NH4OAc (pH 7) extract in FES 589 nm \\
\hline Available Ca & $\begin{array}{l}\text { NH4OAc (pH 7) extract by complexometric } \\
\text { titration method, involving ethylene diamine } \\
\text { tetra-acetic acid (EDTA) }\end{array}$ \\
\hline
\end{tabular}

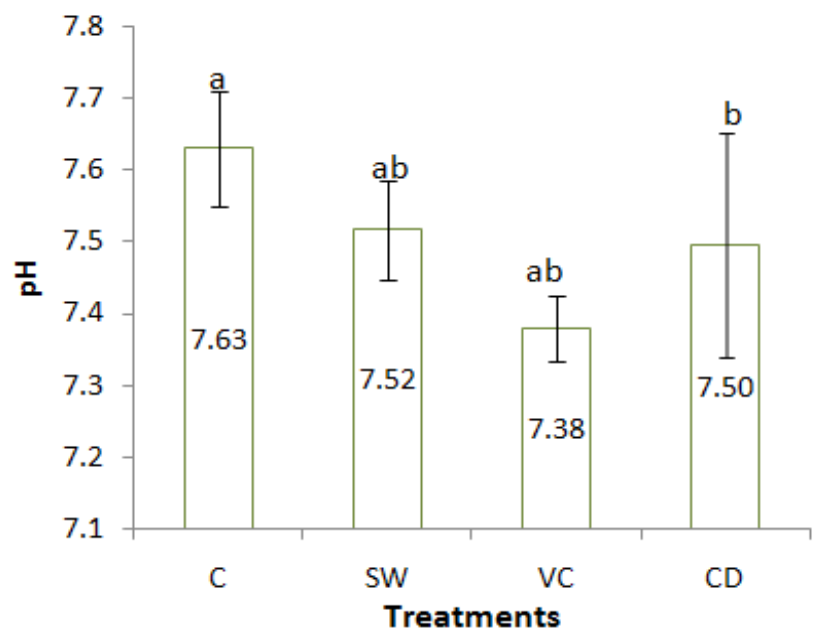

Fig. 2: Effect of organic amendments treated soil on soil pH 


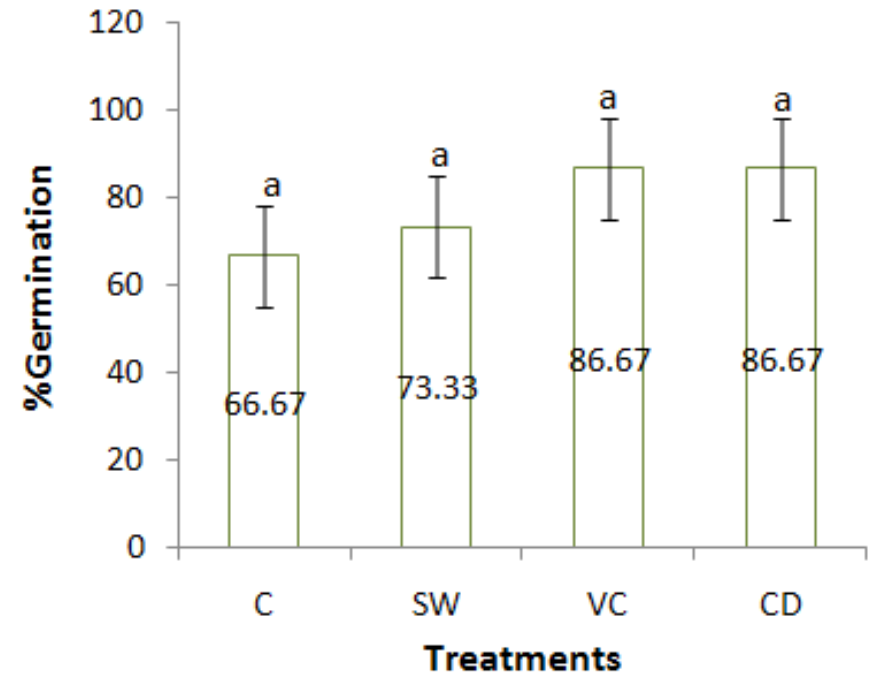

Fig. 3: Effect of organic amendments mixed soil on germination rate of maize

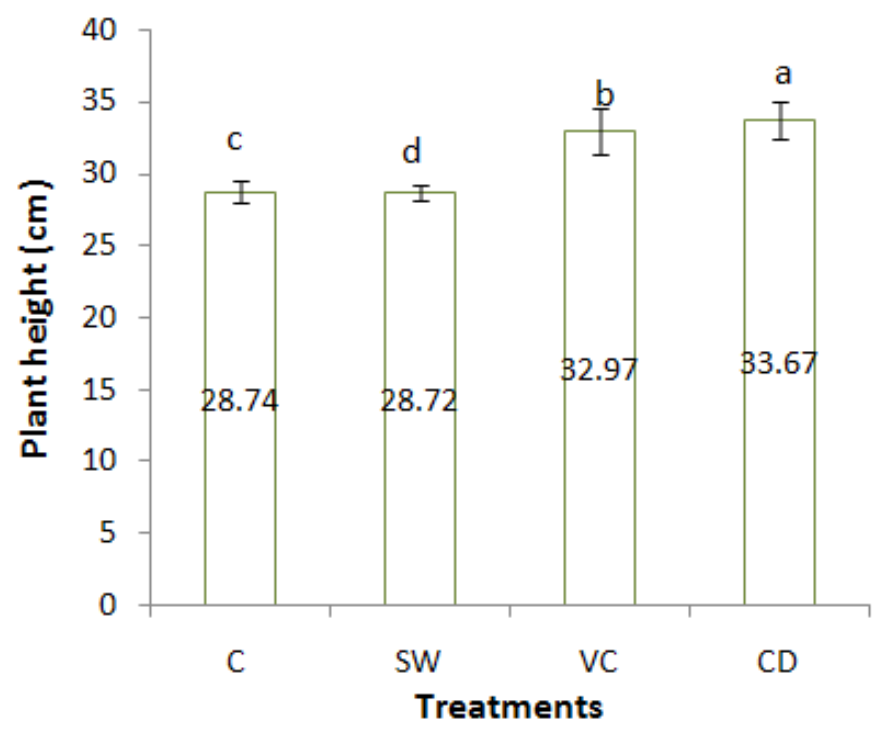

Fig. 5: Effect of organic amendments mixed soil on plant height $(\mathrm{cm})$ of maize

\section{Sample analysis}

Standard methods for the determination of samples physico-chemical properties were followed that were presented in Table 1. General properties of soil, water and organic amendments were measured and presented in Table 2. Table 3 presented the coding of experiment.

Table 2. Properties of soil, water and organic amendments

\begin{tabular}{lllll}
\hline Samples & EC (dS/m) & $\mathbf{p H}$ & \% Ca (Available) & $\begin{array}{l}\text { \% Na } \\
\text { (Available) }\end{array}$ \\
\hline Soil & 10.6 & 7.63 & - & 0.29 \\
\hline River water & 4.28 & 8.17 & - & - \\
\hline Solid waste & 6.56 & 7.78 & 0.16 & 0.43 \\
\hline Vemicompost 1.85 & 6.65 & 0.8 & 0.34 \\
\hline Cow dung & 4.67 & 6.84 & 1.76 & 0.31 \\
\hline
\end{tabular}

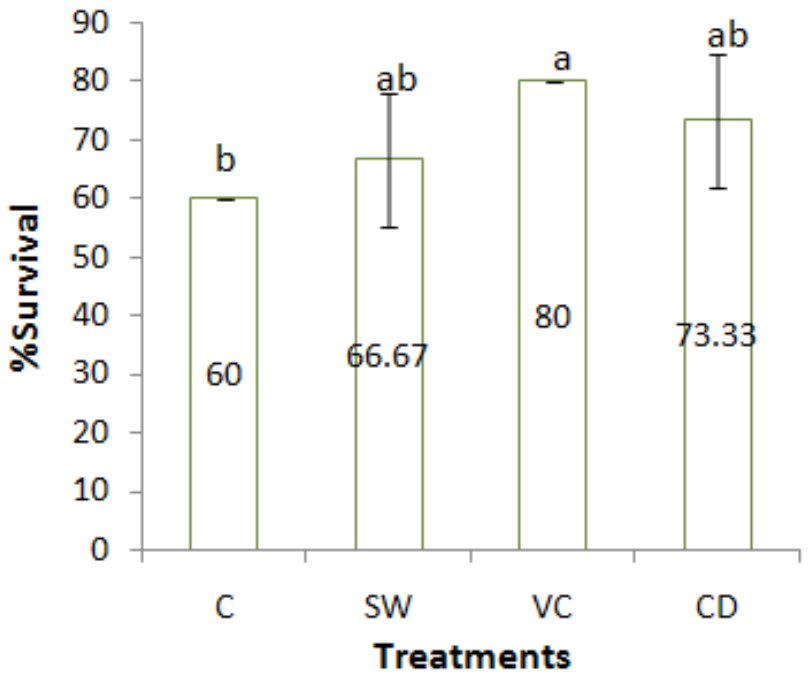

Fig. 4: Effect of organic amendments mixed soil on survival rate of maize

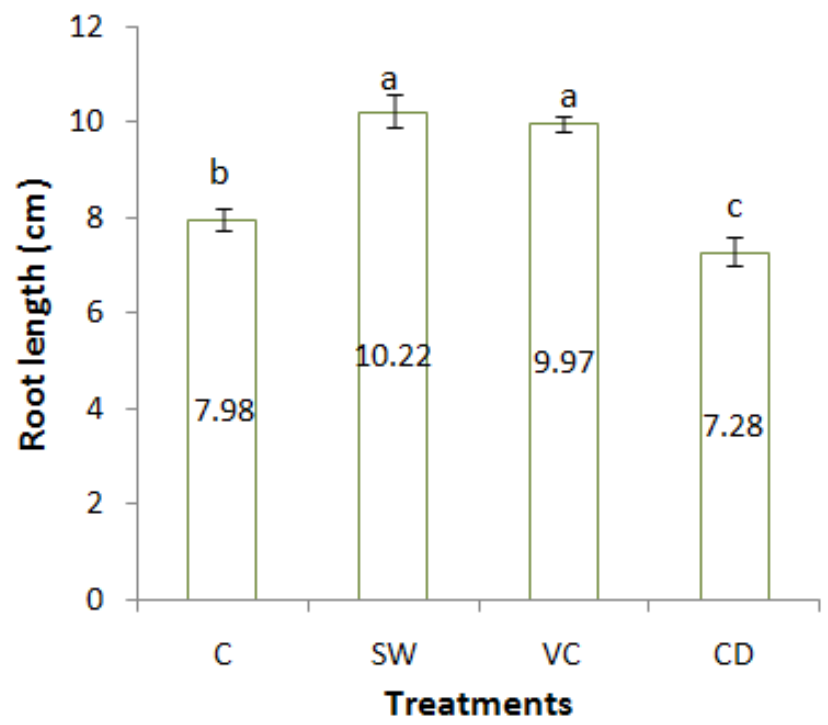

Fig. 6: Effect of organic amendments mixed soil on root length $(\mathrm{cm})$ of maize

\section{Experimental design:}

An experiment was conducted during kharif 1 season in 2015 within earthen pots in Khulna University campus. The experiment was carried out in a completely randomized design (CRD) with 3 replications. The total number of pots used in the study was 12 . Each pot was $15 \mathrm{~cm}$ deep with $17 \mathrm{~cm}$ diameter at the top and was filled with $5 \mathrm{~kg}$ of air dried soil. The EC level of the soil was measured $10.6 \mathrm{dS} / \mathrm{m}$. Solid waste (SW), Vermicompost (VC), and Cow dung (CD) were incorporated with the pot soils and incubated for 15 days before seed sowing. Table 3 presented the coding of experiment. The amount of organic manures was calculated according to the available $\mathrm{Ca}$ amount that can replace available $\mathrm{Na}$ of the pot's soil. The experiment comprised of four treatments viz. T0: Control (No organic manure); T1: Solid waste (36g); T2: Vemicompost (72g); T3: Cow dung (33g). Five seeds were sown in each pot. Seeds were treated with Agrosan GN to protect them from seed and soil borne pathogens. Chemical fertilizers were not 
used in this experiment. Irrigation was done two times before harvesting: at 20 days after sowing (DAS) and at 40 DAS with river water and rain water was irrigated naturally during the season.

Table 3: Coding of Experiment

\begin{tabular}{ll}
\hline Code & Experiment \\
\hline C & Control soil (No organic amendments) \\
\hline SW & Solid Waste treated soil \\
\hline VC & Vermicompost treated soil \\
\hline CD & Cow dung treated soil \\
\hline
\end{tabular}

\section{Data recording}

At Matured stage (50 DAS), plants height and roots length were recorded by using measuring tape as well as soil sampling was also done from each pot for determination of soil EC and $\mathrm{pH}$.

\section{Statistical analysis}

The collected data were analyzed by following analysis of variance (ANOVA) technique by using statistical software SPSS 16.0 (10) and the mean difference as well as standard deviation was calculated by using Microsoft Excel.

\section{Results}

The soil EC values for different treatments varied from 3.37-10.6 dS/m (Fig. 1). The highest EC value $(10.6 \mathrm{dS} / \mathrm{m})$ was observed in initial control (C) soil whereas the lowest EC value $(3.37 \mathrm{dS} / \mathrm{m})$ was observed in Cow dung (CD) treated soil at matured stage. Result showed that application of organic amendments significantly reduced soil EC rather than control soil statistically (Fig. 1, $p \leq 0.05$ ). The $\mathrm{pH}$ values for different treatments vary from 7.387.63 (Fig. 2). The highest $\mathrm{pH}$ value (7.63) was observed in initial control soil whereas the lowest $\mathrm{pH}$ value (7.38) was observed in Vermicompost (VC) treated soil at matured stage. pH results revealed that application of SD and VC were statistically insignificant with other treatments but CD showed the significant difference with control (Fig. $2, p \leq 0.05$ ). The rate of germination was varied from $66.67 \%$ to $86.67 \%$ (Fig. 3). The highest seed germination percentage $(86.67 \%)$ was observed in Vermicompost (VC) treated soil and Cow dung (CD) treated soil whereas the lowest seed germination percentage $(66.67 \%)$ was observed in control soil (Fig. 3). Though the average seed germination rate was higher in organic amendment treated soil but statistically they were insignificant among the treatments (Fig. 3, $p \leq 0.05$ ). The rate of plant survival percentage was varied from $60 \%$ to $80 \%$. The highest plant survival rate (80\%) was observed in Vermicompost (VC) treated soil whereas the lowest plant survival rate (60\%) was observed in control soil (Fig. 4). The mean length of plant height varied from $28.72 \mathrm{~cm}$ to $33.67 \mathrm{~cm}$. The highest plant height $(33.67 \mathrm{~cm})$ was observed in Cow dung (CD) treated soil whereas the shortest plant height $(28.72 \mathrm{~cm})$ was observed in Solid waste (SD) treated soil (Fig. 5). The plant height was significantly higher in VC treated soil but treatments were statistically significant (Fig. 5, $p \leq 0.05)$. Result revealed that VC, CD treated soil increased plant height rather than control soil. The mean length of plant root length varied from 7.28 $\mathrm{cm}$ to $10.22 \mathrm{~cm}$. The highest plant root length $(10.22 \mathrm{~cm})$ was observed in solid waste (SD) treated soil whereas the shortest plant root length (7.28 $\mathrm{cm})$ was observed in cow dung (CD) treated soil. Treatment SW and VC were insignificant with each other but there was a significant difference between organic amendments treated soils and control soil (Fig. 6, $p \leq 0.05$ ).

Table 4: Status of treatments in matured stage (\% increase or decrease in compare with control, ${ }^{*} p \leq 0.05$ and $n s=$ non significant)

\begin{tabular}{lll}
\hline Parameters & $\begin{array}{l}\text { Status (increase or } \\
\text { decrease) }\end{array}$ & $\begin{array}{l}\text { Value (\%) } \\
\text { Mean } \pm \text { SD }\end{array}$ \\
\hline $\mathrm{EC}$ & Decrease & $42.69 \pm 0.67^{*}$ \\
\hline $\mathrm{pH}$ & Decrease & $2.17 \pm 0.31^{\text {ns }}$ \\
\hline Germination rate & Increase & $24.07 \pm 8.49^{\text {ns }}$ \\
\hline Survival rate & Increase & $22.22 \pm 0.01^{*}$ \\
\hline Plant height & Increase & $10.67 \pm 3.16^{*}$ \\
\hline Root length & Increase & $14.89 \pm 5.20^{*}$ \\
\hline
\end{tabular}

Table 4 stated that organic manure treated soil significantly decreased EC $(42.69 \%, p \leq 0.05)$ which is a good sign in reducing soil salinity. Thought germination rate was not significantly affected (Table $4, p \geq 0.05$ ) but plants height, roots length and plant survival rates were significantly increased in application of organic manures (Table $4, p \leq 0.05)$.

\section{Discussion}

Organic amendments significantly improve the growth of maize under saline condition. This may due to application of organic amendments can improve the concentration of $\mathrm{Ca}^{2+}$ in soil solution thus can replace $\mathrm{Na}^{+}$and reduce salinity. Abou ElMagd et al. (2008) (11) conducted two pot experiments on sweet fennel variety "Dulce" with the combination of two levels of organic manure (with, without) and six saline irrigation water treatments, i.e. well water (Control), 1000, 2000, 3000, 4000 and $5000 \mathrm{ppm}$ Results indicated that organic manure treatment increased all the vegetative growth parameters expressed as plant height, leaf number, fresh and dry weight of the total plant and its organs, green yield, nutrient contents of the leaves and bulbs (N, P and K). Also, $\mathrm{K} / \mathrm{Na}$ ratio, calcium and proline content of bulbs 
were increased by organic manuring. Same result was also found by Liang et al. (2005) (12) where he applied organic fertilizers to reclaim saline soil and found positive results. Prapagar et al. (2012) (13) found that organic amendments were effective in reducing saline soil pH. Mostafa et al. (2012) (14) reported that soil salinity has strong effects on maize seed germination rate. This may due to organic fertilizers increase soil fertility and promote more plant growth than that of control soils. Ozdemir, 2005 (15) reported that organic fertilizer definitely increased nodulation, plant growth in low fertile soil (Marginal land). Ibrahim Zidan et al, 1990 (16) reported that salt did not inhibit maize root growth by reducing the capacity of epidermal cells to acidify their walls. Banaras et al. (2002) (17) reported that saline soil productivity can be improved by applying organic amendments in different crops. Survival rate was significantly higher in vermicompost treated soil. Vermicomposts, which are stabilized organic materials produced by earthworms and microorganisms, have been reported to improve plant germination growth and yields in greenhouse crops (18). Vermicompost has large particulate surface areas that provide many micro sites for microbial activity, strong retention of nutrients, high nutrients content and rich microbial populations (19). Plant height was significantly higher in cow dung treated soil. Abubakar et al. (2018) (20) conducted a research to screen the effect of organic manure (poultry manure \& cow dung) on the vegetative growth of maize and observed that plant height increased by increasing the application of both manure and that was better than that of inorganic fertilizer application.

\section{Conclusion}

The organic amendments significantly influence the physico-chemical properties of the saline soil. Cow dung significantly reduce the soil EC compared to other treatments and vermicompost were found effective in reducing the soil EC (from $10.6 \mathrm{dS} / \mathrm{m}$ to $3.64 \mathrm{dS} / \mathrm{m}$ ) significantly. In case of growth parameters (plant height, root length) of maize the treatments were found significant better in organic amendment treated soil rather than control. The positive result of the research especially in case of reducing EC of the saline soil will bring hope to the local farmers. They can produce at least one more crop in fallow period. In the studied area, organic amendments can be used for mitigating salinity problem and maize can be a good option for cultivation in Kharif-1 cropping season.

\section{Acknowledgements}

The authors thank to all staff of Soil, Water and Environment discipline, Khulna University, Khulna, Bangladesh.

\section{Authors Contribution}

MK initiated the work and experimental design, ARS helped in field work, HR helped in laboratory work and TBS contributed in manuscript writing and corrections.

\section{Competing Interest}

The authors declare that they have no competing interest.

\section{References}

1. FAO, Land and Plant Nutrition Management Service. http://www.fao.org/ag/agl/agll/spush, 2008.

2. SRDI (Soil Resources Development Institute), Saline soils of Bangladesh. SRMAF Project, Ministry of Agriculture, Dhaka, Bangladesh. 2010; pp: 1-60.

3. Karim Z, Hussain SG, Ahmed M. Salinity Problems and Crop Intensification in the Coastal Regions of Bangladesh. Soils Publication No. 33, Soils and Irrigation Division, BARC, Farmgate, Dhaka, Bangladesh. 1990; pp. 1-20.

4. Mondal MK. Management of soil and water resources for higher productivity of the coastal saline rice lands of Bangladesh. [PhD thesis]. University of the Philippines, Los Baños, Philippines, 1997.

5. Gupta SK, Gupta IC. Management of Saline Soils and Waters. Oxford and IBH Publication, New Delhi, 1987.

6. Raafat NZ, Tharwat EER. Improving wheat grain yield and its quality under salinity conditions at a newly reclaimed soil using different organic sources as soil or foliar applications. J Appl Sci Res. 2011; 7: 42-55.

7. Leithy S, Gaballah MS, Gomaa AM. Associative impact of bio- and organic fertilizers on geranium plants grown under saline conditions. Electronic J Environ Agril Food Chem. 2010; 9: 617-26.

8. Mansour MMF, Salama KHA, Ali FZM, Abou Hadid AF. Cell and plant responses to $\mathrm{NaCl}$ in Zea mays cultivars differing in salt tolerance. General Applied Plant Physiology 2005; 31: 29-41.

9. Uddin MJ, Islam MM, Nahar MNA. Basic Agriculture. College gate bonding and printing Mohammadpur Dhaka. 2009; pp. 20-23.

10. SPSS 16.0 for window. SPSS Inc., Chicago. 2004.

11. Abou El-Magd MM, Zaki MF, Abou-Hussein SD. 2008. Effect of organic manure and different levels of saline irrigation water on growth, green yield and chemical content of sweet fennel. Aus J Basic Appl Sc. 2008; 2:9095.

12. Liang $\mathrm{Y}$, Nikolic $\mathrm{M}$, Peng $\mathrm{Y}$, Chen $\mathrm{W}$ and Jiang $\mathrm{Y}$. Organic manure stimulates biological activity and barley growth in soil subject to secondary salinization. Soil Biol. Biochem. 2005; 37: 1185-1195. https://doi.org/ 10.1016/j.soilbio.2004.11.017.

13. Prapagar K, Indraratne SP, Premanandharajah $\mathrm{P}$. Effect of Soil Amendments on Reclamation of Saline Sodic Soil. Tropical Agricultural Research 2012; 23(2): 168-176. http://dx.doi.org/10.4038/tar.v23i2.4648

14. Mostafa AZ, Amato M, Galal MYG, Hamdi A, Lotfy SM. Effects Of Irrigation With Saline Water and Soil Type on Germination and Seedling Growth Of Sweet Maize 
(Zea mays L.). Arab Journal of Nuclear Sciences and Applications 2012; 45(2): 537-47.

15. Ozdemir S. Effects of municipal solid waste (MSW) compost on nodulation, plant growth and mineral composition of chickpea in marginal land. Fresenius Environmental Bulletin 2005; 14(7): 599-604.

16. Ibrahim Z, Azaizeh H, Neumann PM, Does Salinity Reduce Growth in Maize Root Epidermal Cells by Inhibiting Their Capacity for Cell Wall Acidification? Plant Physiol. 1990; 93: 7-11. Stable URL: http://www.jstor.org/stable/4272773 https://doi.org/10.1104/pp.93.1.7

17. Banaras H, Niazi, Rozema J, Badr-uz-Zaman, Salim M. Improvement of Saline Soil Productivity through Farm Yard Manure, Amendment and Coated Seeds for
Fodderbeet Cultivation. Asian Journal of Plant Sciences 2002; 1(2): 82-4. https://doi.org/10.3923/ajps.2002.82.84.

18. Edwards CA, Dominguez J, Arancon NQ. The influence of vermicomposts on plant growth and pest incidence. Soil Animals and Sustainable Development. 2004; pp. 397-420. PMid:15191250.

19. Atiyeh RM, Dominguez J, Subler S, Edwards CA. Biochemical changes in cow manure processed by earthworms (Eisenia andrei) and their effects on plantgrowth. Pedobiologia 2000; 44: 709-24. https://doi.org/10.1078/S0031-4056(04)70084-0.

20. Abubakar,Z. A.andAli,A. D. Screening effect of organic manure on the vegetative growth of maize (Zea mays L.). J. Biosci. Agric. Res. 2018; 16(02): 1356-64. https://doi.org/10.18801/jbar.160218.168. 